\title{
Evaluation of the Vacuum Blood Collection Tube, V-Tube, a Domestic Product for Clinical Chemistry and Thyroid Hormone Assays
}

Sung Jin Jo ${ }^{1}$, Yeong Sic Kim $^{1}$, Sang-Guk Lee ${ }^{2}$, and Jehoon Lee ${ }^{1}$ ${ }^{1}$ Department of Laboratory Medicine, College of Medicine, The Catholic University of Korea; ${ }^{2}$ Department of Laboratory Medicine, Yonsei University College of Medicine, Seoul, Korea

Corresponding author: Jehoon Lee Department of Laboratory Medicine, Yeouido St. Mary's Hospital, College of Medicine, The Catholic University of Korea, 10 63(yuksam)-ro, Yeongdeungpo-gu, Seoul 07345, Korea

Tel: +82-2-3779-1297

Fax: +82-2-3779-2285

E-mail: lyejh@catholic.ac.kr

pISSN: $2384-2458$

eISSN: 2288-7261
Background: It is known that the blood collection tube used can cause fluctuations in laboratory test results. We compared test results obtained when blood was collected in V-tube (AB Medical, Korea), BD Vacutainer Tubes (BD, USA), and Greiner Vacuette Tubes (Greiner, USA) in clinical chemistry and thyroid hormone assays.

Methods: One hundred volunteers from three hospitals were recruited and the peripheral blood samples were collected in each of the three serum separation tubes (SSTs). These samples were used for 28 routine clinical chemistry assays and three thyroid hormone assays. The results were analyzed by the Student paired $t$-test and the Bland-Altman plot. For stability tests, the initial results were compared with the day 1 ( $24 \pm 2$ hours), day 3 ( $72 \pm 2$ hours), and day 7 (168 \pm 2 hours) results, respectively.

Results: The difference in the test results obtained from the samples in each tube (V-Tube vs. BD-Tube, V-Tube vs. Greiner-Tube, and BD-Tube vs. Greiner-Tube) were satisfied with the Clinical Laboratory Improvement Amendments of 1988 allowable difference ranges. Except for four analytes (low-density lipoprotein cholesterol, magnesium, potassium, and thyroidstimulating hormone), all analytes were within the allowable critical difference range based on biological variability. The paired $t$-test revealed significant differences between the results of nine assays for samples in V-Tube vs. BD-Tube and seven assays for samples in V-Tube vs. Greiner-Tube, but each set of results showed good correlations. The test results on different days showed a significant difference in several assays, but they were within the allowable difference range.

Conclusions: The assay results for blood samples collected in SST V-Tubes were comparable to those obtained when blood was collected in BD Tubes and Greiner Tubes, and the blood collected in V-Tubes also showed excellent results in the stability tests.

(J Lab Med Qual Assur 2018;40:211-222)

Key Words: Serum separation tube, Chemistry, V-Tube

Received July 17, 2018, Revision received September 18, 2018, Accepted October 2, 2018

\section{서론}

적절한 혈액 채취와 검사의 진행은 정확한 검사결과를 만드 는 검사 전 요소이다. 진단검사항목에서 채혈관의 품질과 올 바른 취급은 검사결과에 큰 영향을 줄 수 있음에도 불구하고 중요성에 비하여 많은 관심을 받지 못하고 있다[1]. 검사실에 서 시행되는 많은 검사들은 채혈관을 이용하며 그 중 진공채 혈관은 정해진 용량을 담을 수 있는 기능과 더불어 검체의 보
관 및 취급자의 보호에 장점이 있어서 1940년대 개발된 이래 로 널리 사용되고 있다[2]. 초창기에는 유리 재질의 채혈관이 사용되었고 산업소재의 발전과 취급상의 편리함 때문에 현재 는 대부분 용도에서 플라스틱 재질의 채혈관이 사용된다. 진공 채혈관은 용도에 따라 항응고제와 clot activator 및 polymer gel 등을 포함하여 시판되며 이러한 물질들 또한 검사결과에 영향을 미칠 수 있는 요소이다[3]. 현재 우리나라에서는 수입 제품인 Becton Dickinson사의 Vacutainer 진공채혈관(BD, 
Flanklin Lakes, NJ, USA)과 Greiner사의 Vacuette 진공채 혈관(Greiner Bio-One, Monroe, NC, USA)의 점유율이 높 다[4]. 진공채혈관의 소재와 첨가물은 제품의 유통과정이 제 품의 품질에 영향을 미칠 수 있고 결과적으로 검사결과에 영향 을 줄 수 있으므로 국내에서 생산되고 유통될 수 있는 진공채 혈관이 정확하고 안정적인 검사를 위하여 필요할 것이다[5].

본 연구에서는 일반화학검사와 갑상선호르몬검사 총 31 가지 검사항목에 대하여 국산 진공채혈관인 $\mathrm{V}$-Tube $(\mathrm{AB}$ Medical, Gwangju, Korea)와 수입제품인 BD Vacutainer 및 Greiner Vacuette를 비교분석하여 성능을 평가하였다.

\section{재료 및 방법}

\section{1. 연구대상}

이 연구는 2017년 11월 한 달 동안 3개의 병원에 내원한 환 자 또는 연구에 동의한 건강한 지원자 등 총 100 명(여의도성 모병원 20명, 성빈센트병원 40명, 신촌세브란스병원 40명) 의 참여자를 대상으로 시행하였다. 대상자는 모두 18 세 이상 의 성인들로 모든 시행과정은 각 병원의 임상연구심사위원회 (institutional review board) 승인을 받고 동의서를 받아 진행 하였다(SC17DNDI0033).

\section{2. 방법}

\section{1) 검체 채취}

지원자를 대상으로 정맥 채취한 혈액을 일반화학검사 및 갑상선호르몬검사를 위해 serum separator tube (SST) 에 담았다. 진공채혈관 needle holder (BD)와 multi draw $21 \mathrm{G}$ needle (Greiner)를 사용하였으며, 채혈된 혈액을 각각 AB Medical사의 SST V-Tube (V-Tube), BD Vacutainer SST Tube (BD-Tube), Greiner사의 Vacuette SST Tube (Greiner-Tube)에 담았다. 채혈 후에는 채혈관을 여러 번 부 드럽게 흔들어 응고활성제(clot activator)에 잘 반응하도록 하 였다. 채취된 검체는 채혈관 제조사에서 권고하는 사용법에 따 라 채혈 후 15 분 혹은 30 분 방치 후 $3,000 \mathrm{~g}$ 으로 6 분간 원심분 리하였으며, 모든 혈액 검체는 채혈 후 2 시간 이내에 검사를 진행하였다. 혈청은 분리젤(separator gel) 위에 있는 상태로 검사하였다. 채혈 당일 검사는 실온에 보관한 후 채혈 후 2시 간 이내에 검사하였고, 채혈 후 1 일, 3 일, 7 일 검사는 $4^{\circ} \mathrm{C}$ 냉장 보관 후 시행하였다.

\section{2) 검사항목}

검사항목은 일반화학검사 중 아스파테이트 아미노전이 효소(aspartate aminotransferase, AST), 알라닌 아미 노전이효소(alanine aminotransferase), 알칼리성인산분 해효소(alkaline phosphatase), 감마-글루타밀전이효소 (gamma-glutamyltransferase), 총 단백(total protein), 알 부민(albumin), 혈액요소질소(blood urea nitrogen), 크레 아티닌(creatinine, $\mathrm{Cr}$ ), 총 빌리루빈(total bilirubin), 직접 빌리루빈(direct bilirubin), 중성지방(triglyceride), 총 콜레 스테롤(total cholesterol), 고밀도지단백 콜레스테롤(highdensity lipoprotein cholesterol, HDL-C), 저밀도지단백 콜 레스테롤(low-density lipoprotein cholesterol, LDL-C), 포 도당(glucose), 요산(uric acid, UA), 칼슘(calcium), 무기인 (inorganic phosphorus), 크레아틴키나제(creatine kinase), 아밀라제(amylase), 젖산탈수소효소(lactate dehydrogenase, $\mathrm{LD})$, 마그네슘(magnesium, $\mathrm{Mg}$ ), 철(iron), 불포화철결합능 (unsaturated iron binding capacity), 리파제(lipase), 나트 륨(sodium), 칼륨(potassium, $\mathrm{K}$ ), 염소(chloride, $\mathrm{Cl}$ ) 등의 총 28가지 항목과 갑상선 호르몬검사 총T3 (triiodothyronine, $\mathrm{T} 3$ ), 유리T4 (free thyroxine, free T4), 갑상샘자극호르몬 (thyroid-stimulating hormone, TSH) 등 3가지 항목을 시행 하였다.

\section{3) 참여기관별 분석장비와 반복 검사}

참여기관별 참여 지원자 수는 여의도성모병원 20 명, 성빈 센트병원 40명, 세브란스병원 40명이었고, 그 중 여의도성모 병원의 20예는 채혈 후 2 시간 이내( $\mathrm{t}=0$ hours), 채혈 후 24 시간 $(\mathrm{t}=24 \pm 2$ hours $)$, 채혈 후 3 일( $\mathrm{t}=72 \pm 2$ hours $)$ 그리 고 채혈 후 7일 $(\mathrm{t}=168 \pm 2$ hours $)$ 에 제조사별 각각의 tube 로 재검을 실시하여 검사결과 차이를 비교하였다. 여의도성모 병원의 일반화학검사 장비는 Cobas c702 (Roche Diagnosis System, Basel, Switzerland), 갑상선호르몬검사 장비는 DXI 800 (Beckman Coulter, Brea, CA, USA)이었고 성빈센트 는 AU5800 (Beckman Coulter), DXI 800 장비 그리고 세브 란스병원은 Hitachi 7600 (Hitachi Hitechnologies, Tokyo, Japan)과 Architect i2000ss analyzer (Abbot Laboratories, Abbot Park, IL, USA)였다.

\section{3. 통계분석}

V-Tube, BD-Tube, Greiner-Tube의 검체 채취 후 2시 간 이내의 검사결과는 각각 항목별로 쌍체비교법을 사용하 


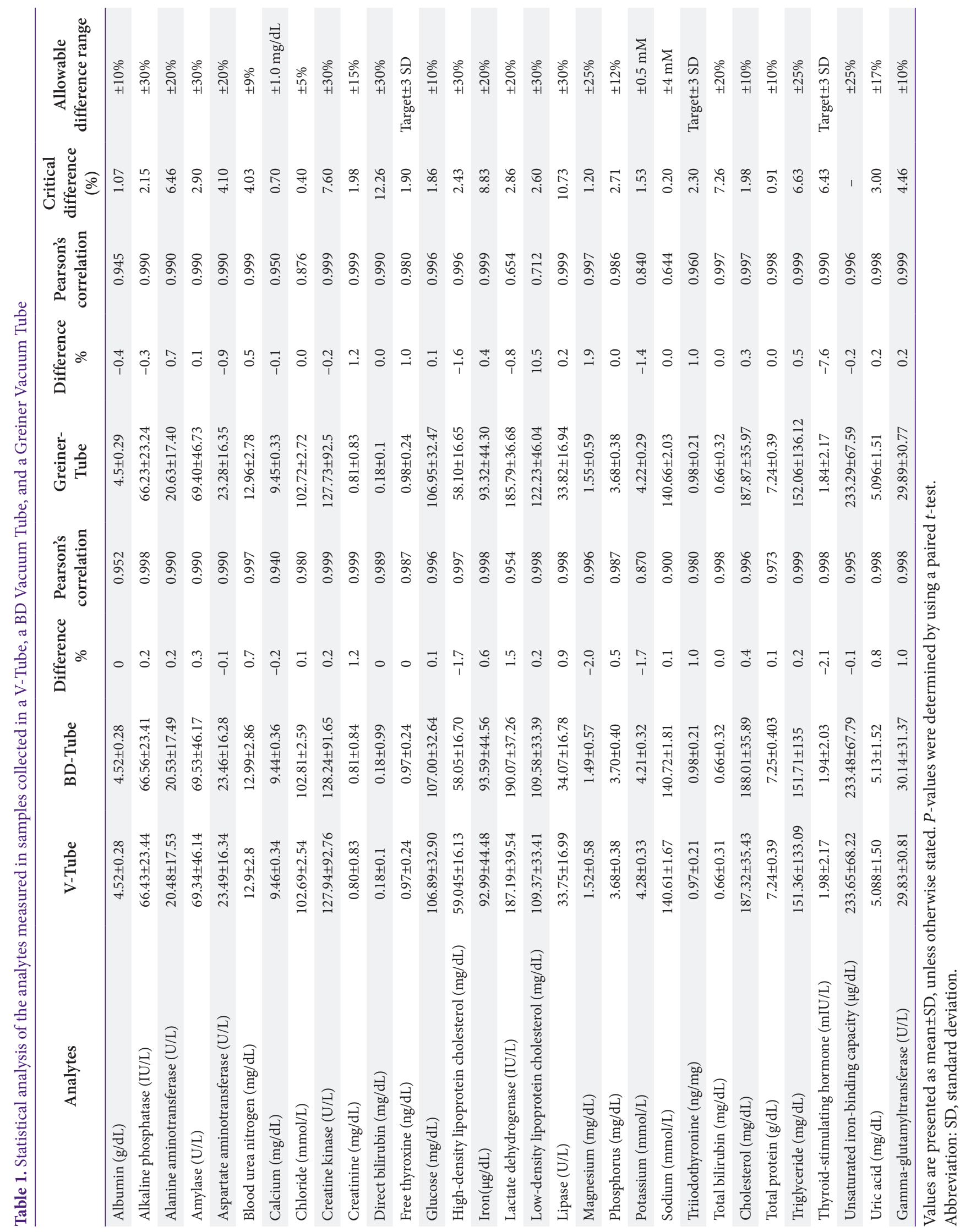


여 비교분석하였다. 각 채혈관별 결과값의 상관관계는 결과값 의 특성에 따라 simple correlation analysis 또는 Spearman correlation analysis를 사용하였다. 각 채혈관별 결과값이 표 준편차의 1.96배 이상 나는 차이를 Bland-Altman plot을 이 용하여 분석하였다. 채취 2 시간 이내, 1 일, 3 일, 7 일의 비교를 위해서 날짜별로 쌍체비교법과 반복 측정 분산분석(repeated measures analysis of variance)을 이용하였다. 각 튜브 간 검
사결과값의 차이 비교는 Clinical Laboratory Improvement Amendments of 1988 (CLIA'88)가 제시하는 허용범위 (allowable difference range)를 참고하였다. 또한 Clinical and Laboratory Standards Institute GP34-A 지침에서 채 혈관 평가방법으로 제시하고 있는 임상적 허용범주에 대한 평가방법 중 하나인 생물학적 변동성(biological variability) 을 검사결과를 비교하는 데 참고하였고〔6], Westgard $\mathrm{QC}$
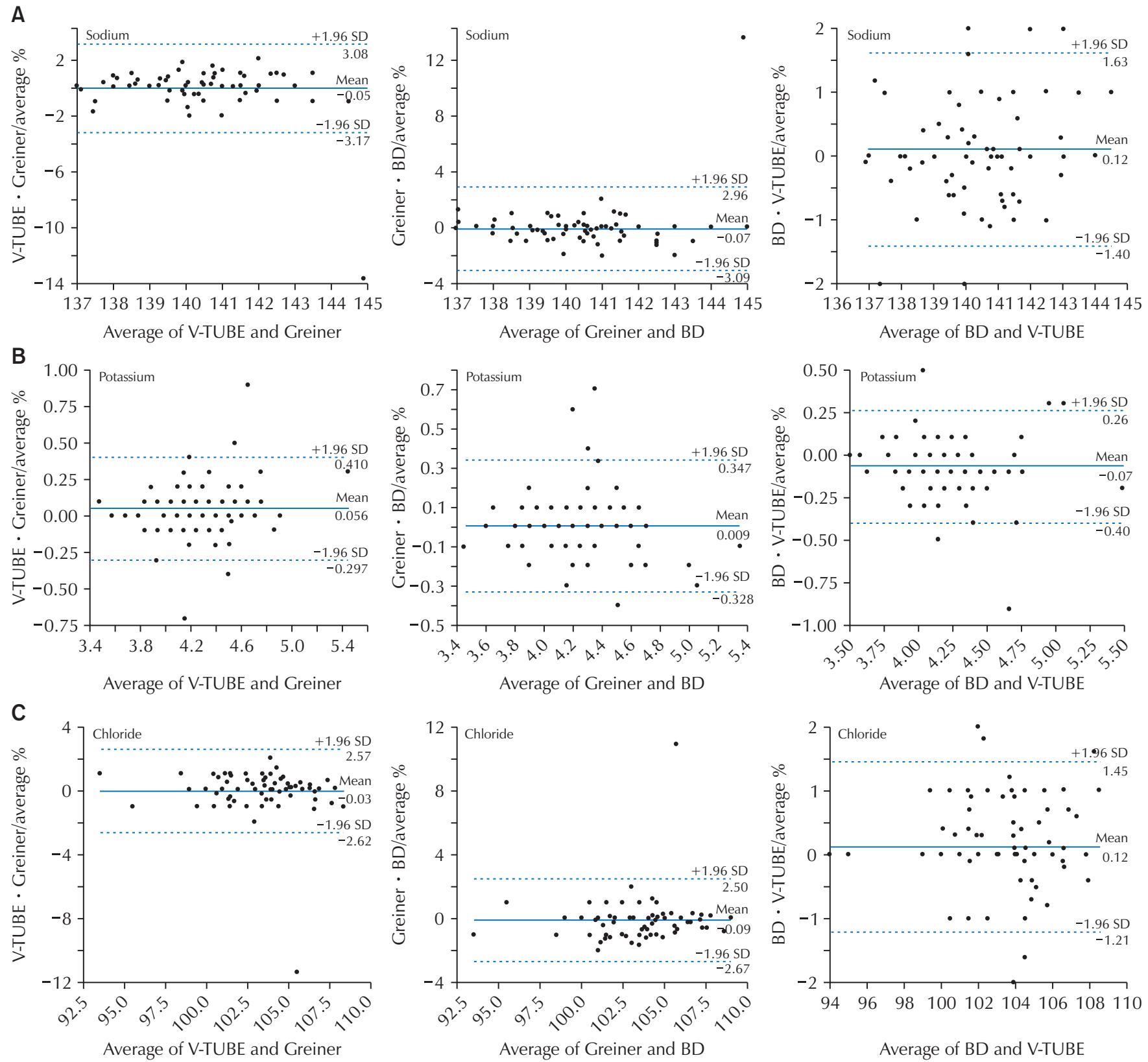

Fig. 1. Bland-Altman plot of the chemical tests in samples collected in V-Tubes, BD Vacutainer and Greiner Vacuette (A, sodium; $\mathrm{B}$, potassium; C, chloride). Abbreviation: SD, standard deviation. 
database에 근거한 허용가능차이(allowable difference, critical difference)는 Table 1에 제시하였다[7]. 통계분석은 통계프로그램인 Analyse-it ver. 4.95 (Analyse-it Software Ltd., Leeds, UK)을 사용하였다.

\section{결과}

100 명을 대상으로 시행한 채혈 후 2 시간 이내에 측정한 일 반화학검사와 갑상선호르몬검사에 대한 채혈관 간 비교는 Table 1에 정리하였다. 3 개의 채혈관 간 결과값의 차이는 모든 측정항목에서 CLIA'88가 제시하는 허용범위를 만족하였다. 생물학적 변동성에 근거한 허용가능차이(critical difference) 를 벗어난 항목은 V-Tube와 $\mathrm{BD}-\mathrm{Tube}$ 에서는 $\mathrm{Mg}$ 과 $\mathrm{K}$ 이었고, V-Tube와 Greiner-Tube에서는 LDL-C, Mg, TSH이었다. $\mathrm{V}$-Tube와 BD-Tube의 결과값을 쌍체비교법을 통하여 비교 하였을 때 유의한 차이 $(P<0.05)$ 를 보인 항목은 $\mathrm{Cr}, \mathrm{HDL}-\mathrm{C}$, iron, $\mathrm{LD}$, lipase, $\mathrm{Mg}, \mathrm{K}$, total cholesterol 그리고 UA였다. 그러나 이들 항목의 결과값은 강한 양의 선형 상관관계를 보
였다. 이들 항목 중 상관계수가 가장 낮은 항목은 potassium 이었다(rho>0.870). V-Tube와 Greiner-Tube 결과값을 쌍 체비교법을 통하여 비교하였을 때 유의한 차이를 보인 항목은 AST, direct-bilirubin, $\mathrm{HDL}-\mathrm{C}, \mathrm{LDL}-\mathrm{C}, \mathrm{Mg}, \mathrm{K}$ 그리고 TSH 였으나 모두 강한 양의 선형 상관관계를 보였고 가장 낮은 상 관계수를 보인 항목은 $\mathrm{LDL}-\mathrm{C}$ 였다(rho>0.712). BD-Tube 와 Greiner-Tube 간 유의한 차이를 보인 항목은 $\mathrm{Cr}$, direct bilirubin, T4, LD, LDL-C, lipase, Mg, T3, total bilirubin, $\mathrm{TSH}$, UA 등 11 개 항목이었다.

각 채혈관의 결과값 차이를 Bland-Altman plot으로 분석한 결과, 제조사별 결과값이 표준편차 1.96배 이상으로 증가한 경 우는 각 측정항목에 따라 적게는 1 개에서 많게는 10 개의 검체 까지 있었다. Bland-Altman plot를 벗어나는 결과는 각각의 검사항목당 평균 V-Tube/BD-Tube 4.9건, V-Tube/GreinerTube 4.6건, BD-Tube/Greiner-Tube 5.1건이었고 제조사 간 유의한 차이는 없었다. 다른 항목에 비하여 비교적 낮은 상관 계수를 보인 전해질 검사항목의 Bland-Altman plot 그래프는 Fig. 1에 나타내었다. 전해질검사의 각 항목별 튜브 제조사별
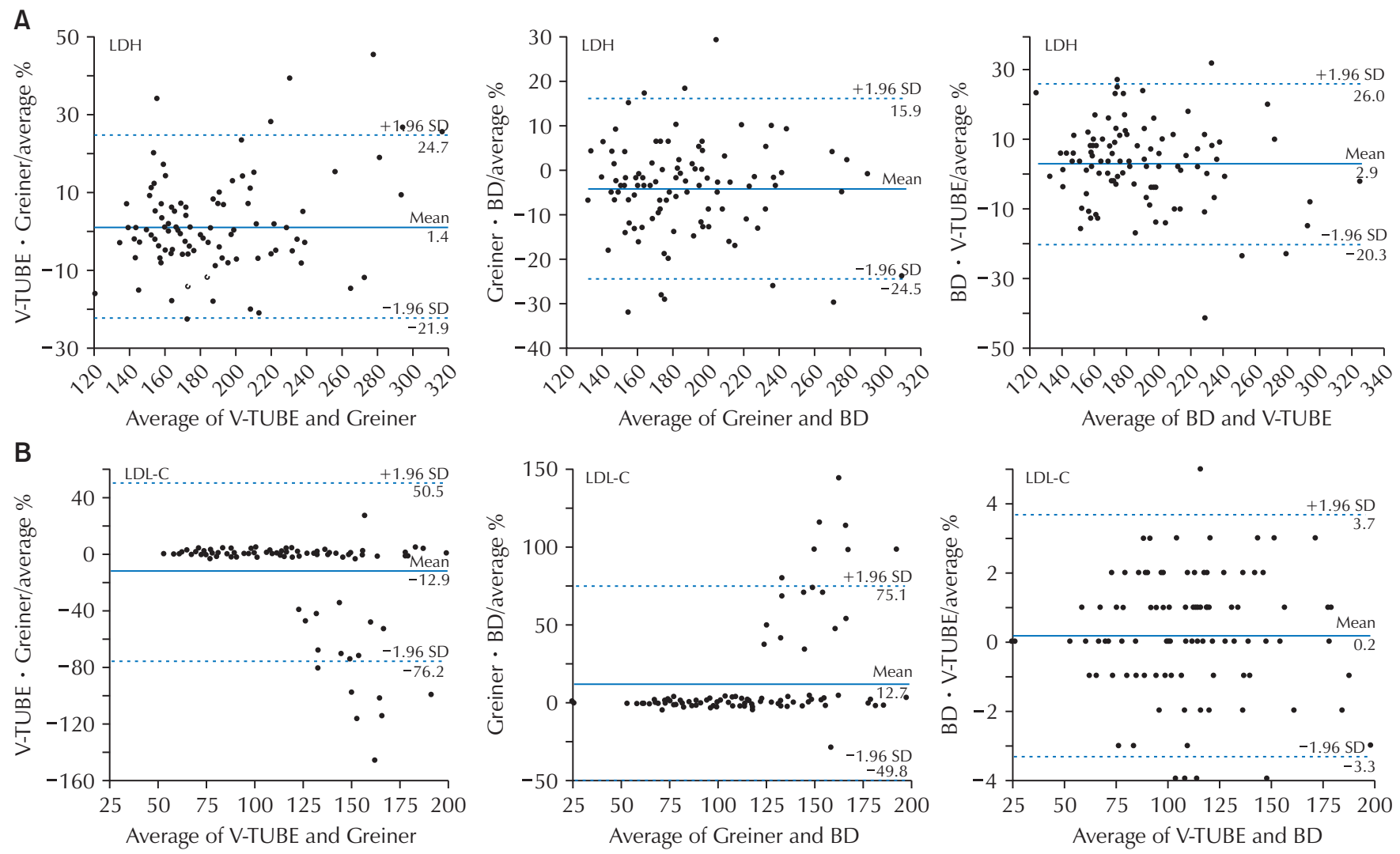

Fig. 2. Bland-Altman plot of the chemical tests in samples collected in V-Tubes, BD Vacutainer and Greiner Vacuette (A, LD; B, LDL-C). Abbreviations: SD, standard deviation; LD, lactate dehydrogenase; LDL-C, low-density lipoprotein cholesterol. 
측정결과값의 특이점은 없었다. 비교적 낮은 상관계수를 보인 $\mathrm{LD}$ 와 LDL-C 항목의 Bland-Altman plot 그래프는 Fig. 2에 나열하였다. 약 $125 \mathrm{mg} / \mathrm{dL}$ 이상의 $\mathrm{LDL}-\mathrm{C}$ 를 측정하는 데 있 어서 Greiner-Tube를 사용한 결과값과 V-Tube나 BD-Tube 를 사용한 결과값 사이에 차이점을 보였다. 갑상선기능검사 의 Bland-Altman plot 그래프를 Fig. 3에 나타내었다. TSH 측정에 있어서 Architect i2000sr analyzer 장비와 GreinerTube를 사용한 검사의 결과값이 다른 tube를 사용한 결과값
과 비교하여 차이점을 보였다.

각 제조사별 tube의 채혈 당일(day 0), 채혈 후 하루(day 1 ), 채혈 후 3일(day 3), 채혈 후 7일(day 7)의 결과값을 비 교하였다(Tables 2-4). 채혈 당일과 각 날짜별 재검결과값의 차이가 통계적으로 유의하지 않은 항목은 V-Tube에서는 $\mathrm{Cl}$, BD-Tube에서는 AST 항목뿐이었고, Greiner-Tube에서는 없 었다. 채혈 당일의 검사결과값과 가장 큰 차이를 보이는 날짜 는 채혈 후 하루의 검사결과값이었다. 채혈 당일(day 0)과 하
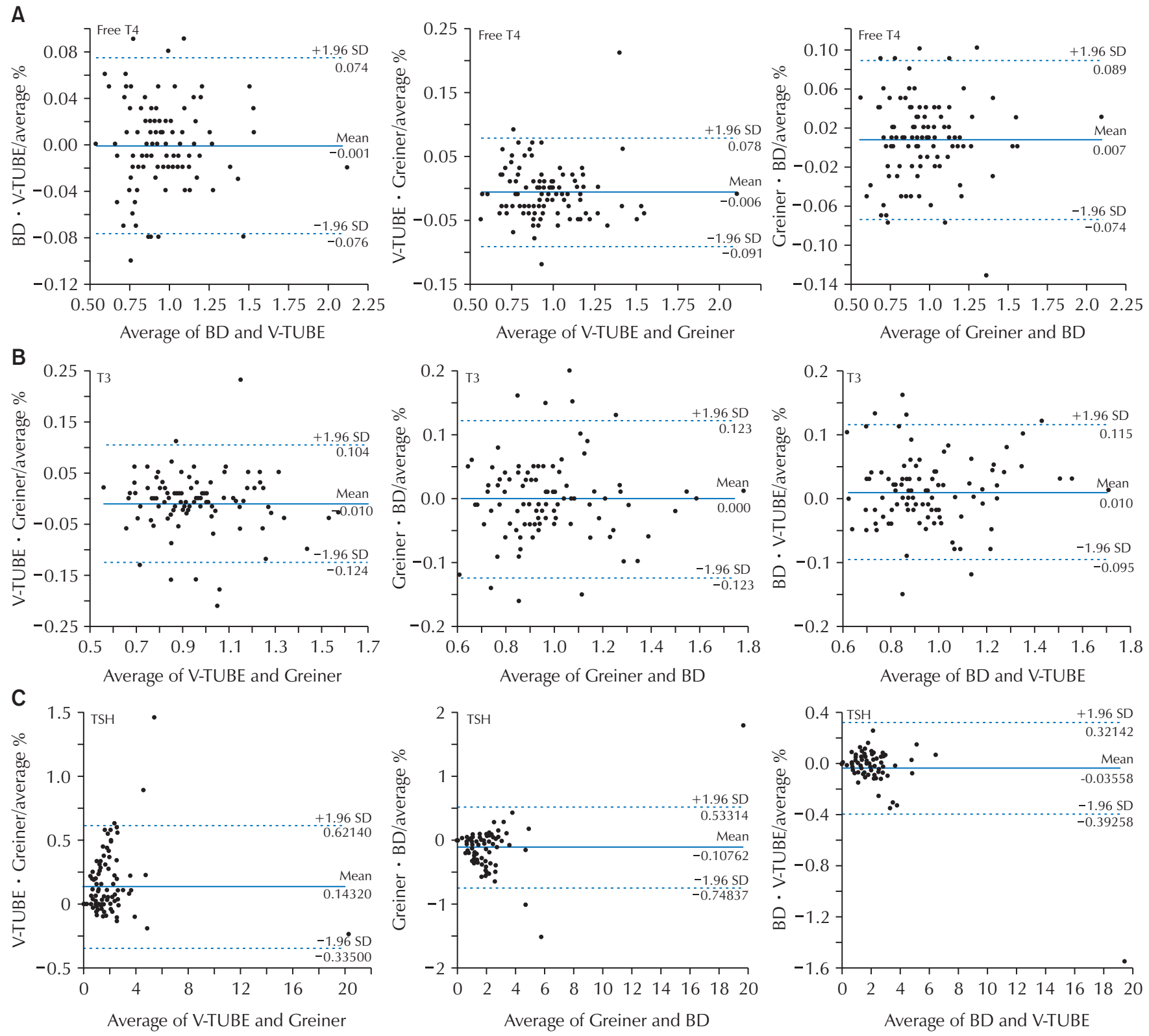

Fig. 3. Bland-Altman plot of the chemical tests in samples collected in V-Tubes, BD Vacutainer, and Greiner Vacuette (A, free T4; B, T3; C, TSH). Abbreviations: SD, standard deviation; T3, triiodothyronine; free T4, free thyroxine; TSH, thyroid-stimulating hormone. 


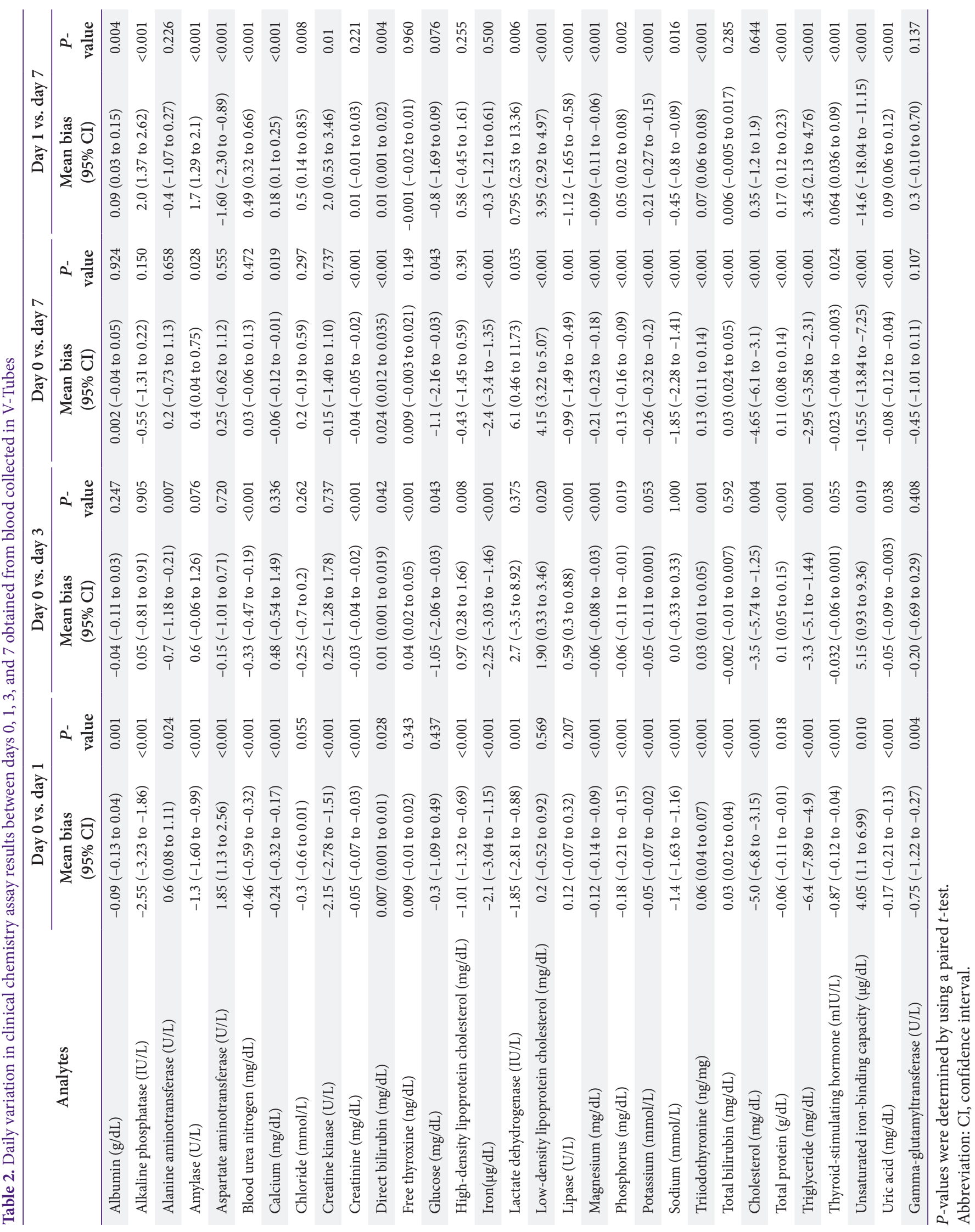




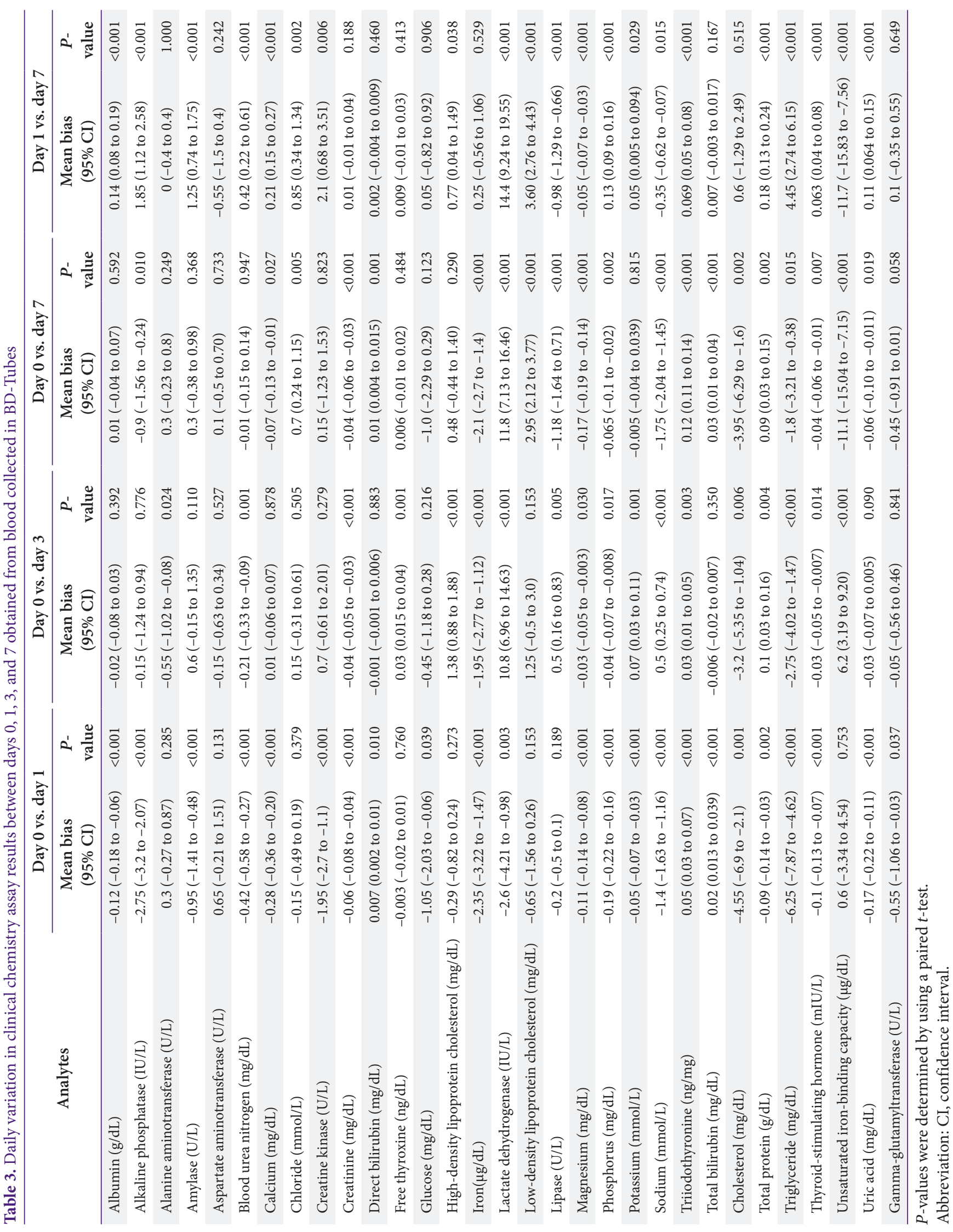




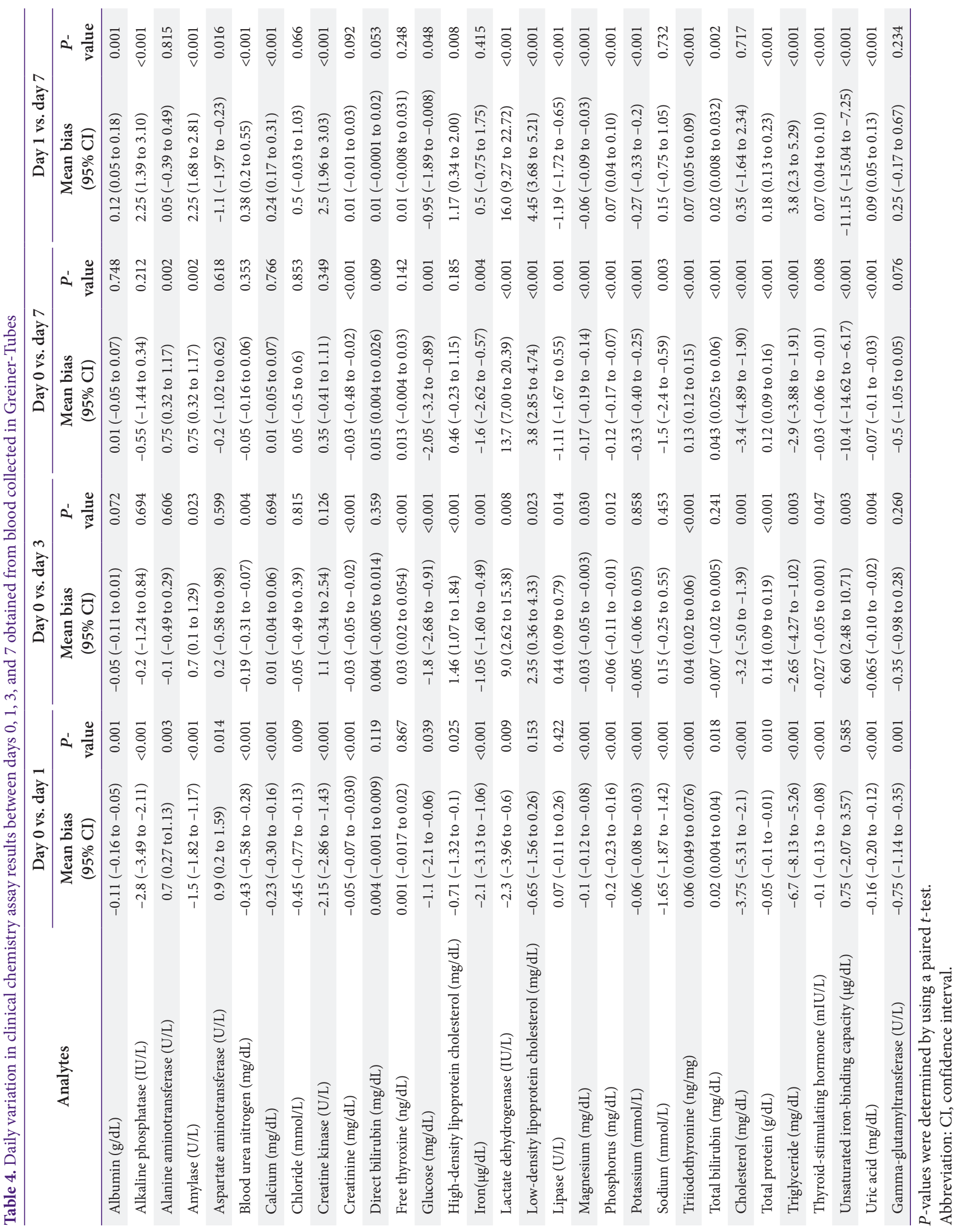




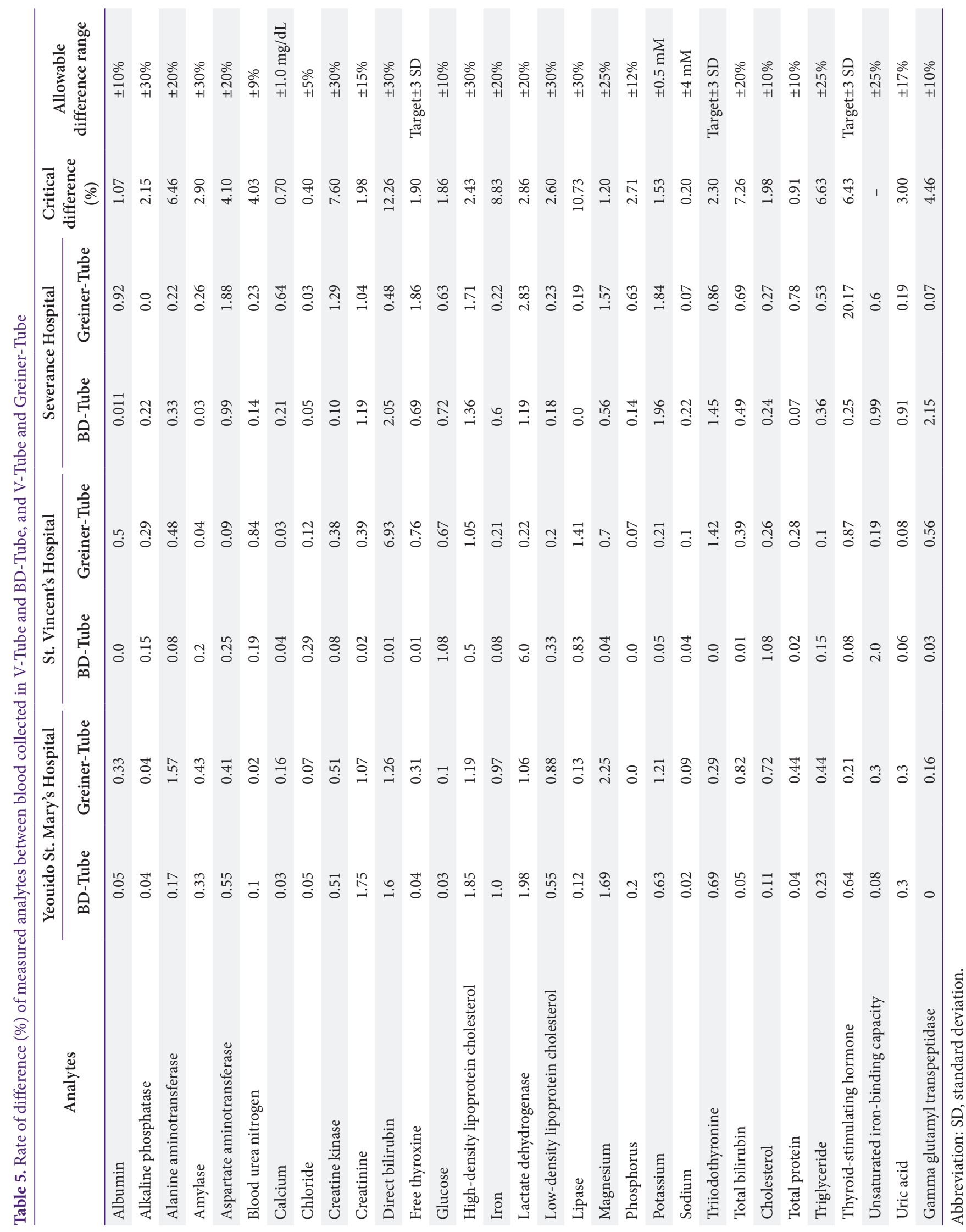


루(day 1) 결과값이 통계적으로 유의한 차이를 보이는 항목 은 V-Tube에서는 26항목, BD-Tube에서는 23항목, GreinerTube에서는 26항목이었다. 채혈 당일 결과값을 기준으로 하 였을 때 각 tube 제조사별 일반화학검사 및 갑상선호르몬검사 의 전체 평균 결과값의 최대 변동폭은 $\mathrm{V}-\mathrm{Tube}$ 가 $1.1 \%, \mathrm{BD}-$ Tube 1.48\%, Greiner-Tube 1.46\%로 V-Tube가 상대적으로 안정적인 변동폭을 보였다. 항목별로는 V-Tube에서는 AST 가, $\mathrm{BD}-\mathrm{Tube}$ 와 Greiner-Tube에서는 $\mathrm{LD}, \mathrm{Mg}$, T3 항목이 다 른 tube에 비하여 큰 변동폭을 보였다.

각 참여기관별 V-Tube와 BD-Tube, Greiner-Tube의 결과 값의 차이는 Table 5에 정리하였으며 3곳의 참여기관에서 시 행한 대부분 항목에서 각 tube별 결과값의 차이는 허용범위 이내로 측정되었다.

\section{고찰}

진공채혈관은 구성재료와 첨가물에 의해서 검사 전 오류에 영향을 미칠 수 있는 정밀성을 요구하는 의료기기의 일종이다 〔1-3]. 또한 자체의 진공능력과 품질관리 또한 검사결과에 영 향을 줄 수 있으며 이에 대한 많은 연구가 있었다 [5,8]. 현재 국내에서 사용되고 있는 진공채혈관은 $\mathrm{BD}$ 와 Greiner 수입 제품이 대부분을 차지하고 있고 국산제품의 시장점유율은 낮 은 편이다. 수입 유통과정에서 발생할 수 있는 품질문제와 그 에 따른 검사결과의 오류 등의 가능성을 고려할 때 국산제품 을 검사실에서 사용한다는 것은 충분히 그 효용성이 있을 것 이다. 그러나 검사결과에 큰 영향을 미칠 수 있는 정밀한 의료 기기라는 점에서 진공채혈관의 검사의 정확성 및 안정성에 대 한 검증은 필수적이다. 본 연구에서는 국내 개발된 진공채혈관 V-Tube와 세계 시장에서 널리 사용되고 있는 $\mathrm{BD}$ 와 Greiner 회사제품의 성능비교를 3개 의료기관이 참여하여 다양한 검사 장비 및 검사환경에 노출하여 평가할 수 있었다.

3 개 제조사의 채혈관 간 일반화학검사 및 갑상선호르몬검 사의 결과값의 차이는 CLIA'88의 허용차 범위를 모두 만족 하였으며, 생물학적 변동성에 근거한 허용가능차이(critical difference)를 대부분 만족하였다. 각 tube별 쌍체비교법을 통한 결과 비교에서는 V-Tube와 BD-Tube의 $\mathrm{Cr}$, HDL-C, iron, $\mathrm{LD}$, lipase, $\mathrm{Mg}, \mathrm{K}$, total cholesterol, UA 등 9항목이 V-Tube와 Greiner-Tube 비교에서는 AST, direct bilirubin, $\mathrm{HDL}-\mathrm{C}, \mathrm{LDL}-\mathrm{C}, \mathrm{Mg}, \mathrm{K}, \mathrm{TSH}$ 의 7항목이 유의한 결과 차이 $(P<0.05)$ 를 보였다. 그리고 BD-Tube와 Greiner-Tube에서 는 총 11 항목이 유의한 결과 차이를 보였다. 그러나 이들은 모 두 강한 양의 선형 상관관계를 보였으며 임상적으로 의미 있는
차이는 아니었다. 지질검사인 total cholesterol이나 LDL-C, $\mathrm{HDL}-\mathrm{C}$ 항목에서 각 채혈관 간 유의한 차이를 보였는데, 특히 $\mathrm{LDL}-\mathrm{C}$ 항목에서 Greiner-Tube의 측정값(mean \pm standard deviation [SD], 122.23 \pm 46.04 )이 V-Tube (mean $\pm \mathrm{SD}$, 109.37 \pm 33.41 )와 BD-Tube (mean $\pm \mathrm{SD}, 109.58 \pm 33.39$ )의 결과와 약 $10 \%$ 차이를 보였다. 이 차이는 Bland-Altman plot 에서 알 수 있듯이 약 $125 \mathrm{mg} / \mathrm{dL}$ 이상의 샘플을 측정할 때 발생하는 경향이 있었다. 이는 각 제조사별 결과값의 차이가 CLIA'88의 임상적 허용범위를 만족하는 범위 내로 작지만, 임 상적 허용 가능값을 벗어나 채혈관 자체가 검사결과에 미치는 요인이 될 수도 있음을 보여주었다.

이번 연구는 3 개의 의료기관에서 참여함으로써 검사의 결 과값이 검사장비와 시약, 그리고 사용자와 같은 검사실환경 의 차이로 인하여 영향을 받을 수 있을 것으로 생각되어 채혈 관의 범용성을 평가해 볼 수 있을 것으로 기대하였다. 각 참 여 의료기관별 채혈관 간 결과값의 차이는 CLIA'88의 허용 범위를 만족하였다. 그러나 TSH 항목에서 Architect i2000sr analyzer 장비로 측정한 40개 검체의 TSH 평균값은 GreinerTube (mean $\pm \mathrm{SD}, 1.38 \pm 0.98$ ) 평균값과 $\mathrm{V}-\mathrm{Tube}$ (mean \pm $\mathrm{SD}, 1.73 \pm 1.23$ )와 $\mathrm{BD}-\mathrm{Tube}$ (mean $\pm \mathrm{SD}, 1.73 \pm 1.25$ )에 비 하여 유의한 차이를 보였다. DXI 800 장비로 측정한 60 개 검 체의 TSH 평균값은 V-Tube (mean $\pm \mathrm{SD}, 2.14 \pm 2.60$ ), BDTube (mean $\pm \mathrm{SD}, 2.08 \pm 2.41$ ), Greiner-Tube (mean $\pm \mathrm{SD}$, $2.13 \pm 2.63)$ 로 tube별 결과값의 큰 차이는 보이지 않았다. 이 러한 결과는 tube의 요인과 그 외 다른 검사환경의 요인이 서 로 결합하여 검사결과에 영향을 줄 수 있다는 점을 시사한다.

혈액 검체를 이용한 검사는 채혈 후 일정한 시간 내에 검사 가 진행되어야 하지만 재검 등과 같은 이유 때문에 시간이 경 과된 후에 다시 검사가 시행될 때도 있다. 각 검사항목별 시간 의 지연에 따른 검사의 결과치의 변화는 많은 문헌들 통하여 예상할 수 있으며, 이번 연구에서는 채혈 당일 2 시간 이내, 채 혈 후 하루, 채혈 후 3 일, 채혈 후 7일의 결과값을 측정하여 채 혈관 제조사별로 그 변화치를 확인하였다. 시간 경과에 따른 변동폭은 3종류의 채혈관 모두 CLIA'88를 만족하였다. 하지 만 검체 채취 후 1 일 후의 결과가 가장 큰 폭의 변화를 보이므 로 결과해석 시에 참고할 수 있겠다.

결론적으로, 본 연구에서는 임상검사실에서 사용되는 진공 채혈관의 제조사별, 보관일수에 따라 생화학검사 및 갑상선검 사에 영향을 줄 수 있음을 확인하였으며, 국산 진공채혈관인 $\mathrm{V}$-Tube가 수입 채혈관과 동등한 성능과 안정성을 갖고 있음 을 확인하였다. 


\section{Journal of LABORATORY MEDICINE and QUALITY ASSURANCE}

Sung Jin Jo et al $\bullet$ Evaluation of the V-Tube

\section{REFERENCES}

1. Bowen RA, Remaley AT. Interferences from blood collection tube components on clinical chemistry assays. Biochem Med (Zagreb) 2014;24:31-44.

2. MacNutt MJ, Sheel AW. Performance of evacuated blood collection tubes at high altitude. High Alt Med Biol 2008;9:235-7.

3. Bush VJ, Leonard L, Szamosi DI. Advancements in blood collection devices. Lab Med 1998;29:616-22.

4. Oh SH, Ki CS. Comparison of two new plastic tubes (Sekisui INSEPACK and Green Cross Green Vac-Tube) with BD Vacutainer Tubes for 49 analytes. Korean J Lab Med 2007;27:69-75.

5. Won EJ, Shin MG, Jang MJ, Cho D, Kee SJ, Kim SH, et al. Comparison between V-Tubes and BD Vacutainer Tubes for use in laboratory tests. Lab Med Online 2013;3:14554.

6. Clinical and Laboratory Standards Institute. Validation and verification of tubes for venous and capillary blood specimen collection; approved guideline: GP34-A. Wayne (PA): Clinical and Laboratory Standards Institute, 2010.

7. Westgard JO. Desirable specifications for total error, imprecision, and bias, derived from intra- and interindividual biologic variation. http://www.westgard.com/ biodatabase1.html (Accessed July 5, 2018).

8. Hwang SS, Yoon KR, Yoon KJ. Comparison of three plastic tubes (two Gongdong Vacuum Blood Tubes and Improve Vacuum Blood Collection Tube) with BD Vacutainer Tube for 37 laboratory tests. J Lab Med Qual Assur 2009;31:301-8. 